\title{
Representing the Arab Spring in the Iranian Press: Islamic Awakening or Foreign-Sponsored Terror?
}

\author{
Rusi Jaspal, Ph.D. \\ De Montfort University, Leicester, U.K.
}

\begin{abstract}
The Islamic Republic of Iran, the largest non-Arab country in the region, has sought to play an influential role in regional politics since its establishment in 1979, and the Arab Spring protests have provided the prime opportunity for doing so. The Iranian government has vocally supported the revolutions in Egypt, Tunisia, and Libya, but has remained defiantly supportive of the Syrian president despite popular opposition to his government. The Iranian media have been pivotal in communicating the position of the Islamic Republic of Iran. Using qualitative thematic analysis and social representations theory, this article examines emerging media representations of the Arab Spring in two major English-language Iranian newspapers, The Tehran Times and Press TV. The following two themes are discussed: (1) "Islamic Awakening": Islamicizing the Arab Spring, and (2) "Bashar Al-Assad is not Muammar Al-Gaddafi": Compartmentalizing the Syrian Ally. Islamic identity and ingroup-outgroup dynamics are mobilized in order to increase the political influence of Iran and to undermine that of its foes. It is argued that there is a systematic "instrumentalization" of the Arab Spring in the Iranian press - it is employed to validate and accentuate tenets of the Islamic Republic of Iran's revolutionary ideology and to support its political interests in the region.
\end{abstract}

\section{KEYWORDS}

Arab Spring; media representations; Iran; Iranian press; groups; politics

\section{CITING THIS ARTICLE:}

Jaspal, R. (in press). Representing the Arab Spring in the Iranian Press: Islamic Awakening or Foreign-Sponsored Terror? Politics, Groups and Identities.

\section{CORRESPONDENCE}

Dr. Rusi Jaspal, Self and Identity Research Group, School of Applied Social Sciences, Faculty of Health and Life Sciences, De Montfort University, Leicester LE1-9BH United Kingdom. E-mail: rusi.jaspal@cantab.net 


\title{
Representing the Arab Spring in the Iranian Press: Islamic Awakening or Foreign- Sponsored Terror?
}

\author{
Rusi Jaspal, Ph.D. \\ De Montfort University, Leicester, UK
}

\section{INTRODUCTION}

The "Arab Spring"1 refers to the unprecedented wave of revolutionary protests which have swept across much of the Arab world since December 2010. What began as an act of self-immolation by a fruit vendor in Sidi Bouzhid, Tunisia, rapidly escalated into widespread protests in the whole of Tunisia, which spread across North Africa and the Middle East. On the whole, protesters have demanded greater social and political freedom and an end to dictatorship, but the outcomes of the Arab Spring protests have varied in accordance with national context. In Egypt, Tunisia, Libya and Yemen, the Arab Spring protests have resulted in regime change and, in some cases, democratic elections have followed. In Jordan, Algeria, Morocco and Kuwait, the major protests that occurred gradually fizzled out in response to promises of social and political reform. Conversely, in Syria and Bahrain, the protests have been violently suppressed by the authorities and through foreign intervention (from Lebanon's Hezbollah and Saudi Arabia, respectively). In the case of Syria, this has escalated into full-scale civil war, in which over 100,000 people are said to have been killed (UN News Service, 2013).

The Islamic Republic of Iran, the largest non-Arab country in the Middle East, has sought to play an influential role in regional politics since its establishment in 1979. The Arab Spring protests have provided the prime opportunity for doing so - the Iranian government has vocally supported the revolutions in Egypt, Tunisia, and Libya, but has remained defiantly supportive of the Syrian president despite popular opposition to his government. The Islamic Republic's position on the Arab Spring is clearly observable in the government-aligned Iranian newspaper media. Since the Arab Spring protests erupted, there has been some important research into the historical, social, political and economic aspects of the protests (Ajami, 2012; Aliboni, 2011; Anderson, 2011; Perthes, 2012;), with some important insights into the position of Iran vis-à-vis the Arab Spring (Dallmayr, 2011; Farhi, 2011). There has also been a focus on the use of social media in the Arab Spring (Khondker, 2011; Wolfsfeld, Segev \& Sheafer, 2013) and, more recently, a focus on newspaper representations of the Arab Spring (Brown, 2012; Galal \& Spielhaus, 2012; Salaita, 2012). However, this growing area of research has not yet examined the ways in which the newspaper media in Iran, an important stakeholder in the region, represent the Arab Spring, despite their important role in shaping social representations of the conflict. Drawing upon Social Representations Theory (Moscovici, 1961, 1988) and the related construct of propaganda (Rouquette, 2003, 2004), this article examines emerging media representations of the

\footnotetext{
${ }^{1}$ It is acknowledged that the term "Arab Spring" is contentious and has been subject to criticism. Some commentators have argued that the term implies a move towards liberal democracy in the Middle East, while others argue that due to the growing influence of Islamism in the region "Arab Spring" is inaccurate. In this article, the term is used, for the sake of simplicity and familiarity to readers, to denote the unprecedented wave of revolutionary protests which have swept across much of the Arab world since December 2010.
} 
Arab Spring in two major English-language Iranian newspapers, The Tehran Times and Press TV, in order to identify the ideological tenets that the Iranian regime wishes to disseminate to the international community.

\section{The Islamic Republic of Iran}

The outcomes of the Arab Spring protests seem to depend at least partly on the positions of other countries. For instance, it is unlikely that the overthrow of Gaddafi in Libya would have been so swift if NATO had not intervened militarily and imposed a no-fly zone. Conversely, Russia's decision to veto a UN resolution condemning the Syrian government's treatment of protesters has partially shielded Bashar al-Assad from international sanction and has enabled him to further resist the rebel insurgency in Syria. As an aspiring pillar of influence in the region, the Islamic Republic of Iran is a country whose position on the Arab Spring is of paramount importance. It has been argued that the Islamic Republic has sought to project its power and influence throughout the Middle East region, partly by attempting to incite "Islamic revolutions" in Shia-dominated countries, such as Iraq and Bahrain (Alhasan, 2011; Karsh, 2002). In many cases, this has led to suspicion and antagonistic relations between the Shiite-dominated Iran and its Sunni neighbours. Accordingly, some commentators have claimed that the Islamic Republic attempts to steer the Arab Spring in ways that favour its own geopolitical interests - i.e. by supporting Shia protests in Bahrain but opposing protests against al-Assad's government in Syria.

Though not an Arab country, Iran has itself felt the repercussions of the Arab Spring within its own borders. Even before the Arab Spring, Iran experienced massive popular protests over an 8-month period between 2009 and 2010 in response to the contested victory of Mahmoud Ahmadinejad in the 2009 presidential elections (Morady, 2011). Furthermore, following the ousting of the Tunisian and Egyptian presidents, respectively, there were renewed protests in Iran. In some cases, these protests were initiated by Iran's Green Movement, which contested the 2009 election results. There was undoubtedly a concern within the Iranian political establishment that the Arab Spring could "spread" into Iran, reignite public concerns surrounding the theocratic political system and thereby potentially destabilize the Islamic Republic.

Thus, the Arab Spring had to be "framed" by its leaders in ways that shielded the Islamic Republic of Iran from threats to its existence. The Iranian government has attempted to present itself as a supporter and guardian of the Arab Spring, rather than as an opponent to it. One means of doing so has been to construct the Arab Spring as an "Islamic Awakening," which accentuates similarities between the 1979 Iranian revolution (which established the Islamic Republic of Iran) and the protests in the Arab world. For instance, on 4 February 2010, Ayatollah Khamenei delivered a sermon following Friday prayers, as a marker of solidarity with the Egyptian and Tunisian people. In it, he accentuated the Islamic character of the Arab Spring revolutions and depicted the 1979 Iranian revolution, which toppled the pro-Western Shah, as the harbinger of independence, justice and democracy. The constructed synergy between the 1979 Iranian revolution and the Arab Spring protests has served to glorify the Iranian revolution and construct it as an exemplary system. The Islamic Republic has consistently sought to capitalize on the Arab Spring by exhibiting its support for "the people" of nations allegedly ruled by "oppressive regimes" such as Egypt, thereby constructing itself as a supporter of freedom and human rights. This has helped to deflect accusations levelled against the Islamic Republic concerning its own 
brutal suppression of human rights, and its widespread persecution of leaders and participants in the Green Movement following the re-election of Ahmadinejad (Farhi, 2011; Kurzman, 2012). In short, there has been a rhetorical alignment of the Islamic Republic alongside the Arab Spring protesters and a constructed opposition to dictatorship and global world order.

Yet, the Islamic Republic of Iran has been overtly selective in its support for the Arab Spring protests. While it celebrated the toppling of Egypt's Mubarak and Libya's Gaddafi, Iran has continued to support and defend the Syrian leader Bashar al-Assad, who is a staunch ally of the Islamic Republic (Lesch, 2011). Although Syria is a secular state, Iran regards Syria (along with Hezbollah and Hamas) as an important pillar of the "Islamic resistance" against the State of Israel. Given the centrality of anti-Zionism in Iranian state ideology, this constitutes an important unifying thread between Syria and Iran (Jaspal, 2013a). Moreover, as a supporter of the Lebanese Shiite movement Hezbollah (itself a proxy of Iran), Syria indirectly safeguards Iran's interests in the region. Consequently, Iran denies that there is popular Syrian opposition to the al-Assad regime but rather reiterates al-Assad's notion of a foreign plot to bring about regime change in Syria, a common argument in Middle Eastern politics (Farhi, 2011). This, when coupled with imagery of a Zionist conspiracy against Islam, has particularly potent mobilizing potential in the Muslim Middle East (Aliboni, 2011; Jaspal, in press). The Islamic Republic attempts to distance the Syrian crisis from the Arab Spring, thereby safeguarding its own political interests. This article demonstrates the heuristic value of Social Representations Theory in examining how the Islamic Republic constructs and disseminates its ideological tenets to the international community.

\section{Social Representations, Propaganda and Media coverage}

Social Representations Theory (Moscovici, 1988) was designed to theorize how abstract and esoteric ideas are diffused among the public and make their transition into societal thinking on a large scale. A social representation is defined as "a system of values, ideas and practices" regarding a given social object (Moscovici, 1973, p. xiii; Moscovici, 1988), as well as "the elaborating of a social object by the community for the purpose of behaving and communicating" (Moscovici, 1963, p. 251). Social representations emerge within a particular context and within particular social groups and create what one might call a shared social reality in which discussion of issues such as the Arab Spring can take place (Billig, 1988).

In his discussion of how representations are formed, Moscovici (1988) outlines two processes that give rise to social representations, namely anchoring and objectification. Anchoring refers to the process of making something unfamiliar understandable by linking it to something familiar (Moscovici, 1988). For a community to develop an understanding of a complex political phenomenon such as the Arab Spring, it must first be named and attributed familiar characteristics. For instance, the term "Arab Spring" itself serves to link the revolutionary protests in the Arab world to the 1989 revolutionary protests in the Soviet Bloc leading to the fall of communism. Objectification is the process whereby unfamiliar and abstract objects are transformed into concrete and "objective" common-sense realities. Physical characteristics are attributed to a non-physical entity, essentially "materializing" the immaterial. Elcheroth, Doise and Reicher (2011) argue that both anchoring and objectification can be regarded as forms of intertextuality since prior representations are invoked in support of new representations.

The notion of propaganda is central to Social Representations Theory. In his early research 
into psychoanalytic theory in French society, Moscovici (1961) distinguished between the various ways in which the French newspaper media communicated about the theory. He invoked the notion of propaganda, which constructs antagonistic relations between groups and attempts to destroy rival belief systems by delegitimizing them, while forwarding the ingroup's belief system. Moscovici identified propaganda as the predominant means of communication among the communist milieu, given that communication rested upon the systematic emphasis of intergroup incompatibility and conflict. Thus, propaganda is a markedly ideological means of communication, and it seeks to transform ideology into culture, that is, common-sense thinking. Propaganda attempts to impose uniformity of representations and hegemony upon these representations. Moscovici (1961, p. 314) argues that propaganda becomes a "mode of expression used by a group in a situation of conflict and as the instrumental or action-oriented elaboration of that group's representation of the object of the conflict". It is usually aimed at maintaining the uniformity, integrity and indeed continuity of the group's identity (Wagner et al., 1999). Rouquette (2003, 2004) has highlighted the following four functions of propaganda, which are of eminent importance to the present study:

- It simplifies a complex social world and provides a concise and seemingly logical account of events;

- It retains and accentuates specific elements of the events, while attenuating or discarding others;

- It assimilates the events to existing ways of thinking within a society;

- It attempts to convince us that we should care.

The English-language Iranian newspaper media provide unique insight into the ways in which the Islamic Republic of Iran attempts to communicate and disseminate its political ideology to the international community through propaganda, primarily because non-Iranians are the intended readership of these outlets. Moreover, such outlets may play a fundamental role in shaping public understanding of political and foreign affairs, particularly among specific ethnic and minority groups in the West. For instance, it is observed that many British Pakistani Muslims manifest suspicion of the Western media which has "come to be regarded as Western propaganda for consumption by its own public" (Ansari, 2005, p. 162). Similarly, Ahmed (2005) has indicated that British Pakistani Muslims may prefer what is perceived as "Muslim media", which they regard as more balanced and accommodating of their Muslim identity. Furthermore, in empirical research, Jaspal $(2011,2014)$ has found that, because many British Pakistani Muslims distrust the Western media, this led some disaffected Muslims to explore alternative news outlets such as Iran's government-aligned The Tehran Times and Press TV, partly because these outlets are regarded as being consistent with Islamic identity.

However, it is acknowledged that the presence of certain themes and representations in the media will not necessarily produce specific media effects and that it would be impossible to demonstrate such media effects in the context of the present qualitative research study. Moreover, this assumption would be incompatible with the Social Representations approach employed in this article. Social representations exist at the level of groups and individuals and facilitate communication. Sources of societal information such as the media can help develop social 
representations, since "[a]s a forum for the discourses of others and a speaker in their own right, the media have a key part in the production and transformation of meanings" (Carvalho, 2007, p. 224). The newspaper media can function as the primary intermediary between politics and citizens and can perform an agenda-setting function, informing readers of the necessity of thinking about, discussing and debating specific political issues even though they may never have thought about these issues before (see Olausson, 2011 for a discussion of this issue in the context of climate change). Both the media and individuals function as co-constructors of social representations (Breakwell, 2001) and, thus, empirical research into public understanding of the Arab Spring at group and individual levels would undoubtedly provide fuller insight into social representations of these political events. This article provides just one perspective on this debate, namely a media perspective. It must be stated that there is an important and dynamic interplay between media representation, identity, and personal experience (Smith \& Joffe, 2013). People may be exposed to social representations in the media but will engage with these representations in accordance with their individual and social identities, which encompass personal experience, social memories, group memberships and other aspects of the self (Jaspal, Nerlich \& Cinnirella, 2014).

Despite acknowledging the complex relationship between media representation, identity and action, it is likely that in the Islamic Republic of Iran, the newspaper media are particularly influential. This is particularly pertinent in the context of propaganda, given the explicit aim to convince the readership of the relevance of the object of representation to their identity. In a largescale survey study of media usage in Iran, Wojcieszak, Smith and Ennayat (2012) found that "[o]verwhelmingly, traditional news media (TV, radio or press) were more frequently selected as the main information sources than new media (the internet or text messages)" (p. 11). In fact, for $45 \%$ of the respondents, newspapers were the most important source of news information, which could be explained by the fact that the Iranian government imposes various obstacles to free access to the Internet. Despite being a signatory to The International Covenant on Civil and Political Rights, which stresses that freedom of expression constitutes a universal right, "the Islamic Republic of Iran continues to ensure access to information is one of the most restricted spheres of activity for all Iranian citizens both within and outside its borders" (Ansari \& Danesh, 2011, p. 7). In his examination of Holocaust denial in Iran, Litvak (2006, p. 280) has argued that "it is likely that ordinary Iranians [..] do believe the propaganda that they are served" in the statecontrolled media, despite the overwhelming and consensually accepted evidence that proves unequivocally that the Holocaust did occur. In making this statement, Litvak demonstrates the potency of the Iranian media in shaping public opinion and public understanding social and political issues, such as the Arab Spring, particularly given the centrality of the propaganda means of communication.

Previous analyses of the Iranian media demonstrate the tendency for newspaper outlets to disseminate news items which are consistent with Iranian state ideology. For instance, the Iranian policy of anti-Zionism (and the delegitimization of the State of Israel) is consistently reproduced in newspaper coverage in Iran (Jaspal, 2014, in press). There is a body of research which examines media practices, journalistic norms, censorship and the long-standing anti-Western position of the Iranian media since the Islamic Revolution (Semati, 2008; Sweetser \& Brown, 2010). Yet, a systematic linguistic study of Iranian media representations of the Arab Spring remains conspicuously absent. Such an analysis is important because it can elucidate which representations 
the Islamic Republic attempts to disseminate to the international community. A preliminary analysis of three major Iranian Persian-language newspapers (Keyhan, Hamshahri and Etelaat) indicated a uniformity of representations, exemplifying the indirect state control of the Iranian press. There was little, if any, variation between representations concerning the Arab Spring. Crucially, the representations disseminated in the Persian-language Iranian media had overlap with those disseminated in the English-language Iranian media. The representational similarity between the Persian- and English-language newspaper outlets was striking - in some cases, newspaper articles appeared to have been translated from Persian to English. This indicates that the Iranian regime seeks to crystallize its ideology internally and to export its ideology beyond its borders. Given the aim to understand how the Iranian regime seeks to construct its policy vis-à-vis the Arab Spring on the international stage, this study focuses solely upon representations of the Arab Spring the English-language Iranian press, although it must be noted that these representations are likely to mirror the sorts of representation observable in the Persian-language Iranian press. This study addresses the following specific research questions: (1) How does the Iranian press thematically construct the Arab Spring?; (2) How does it represent protests in specific Middle Eastern countries; (3) How are attributions of causality and blame managed in coverage?

\section{METHOD}

\section{The corpus}

In order to gain insight into the representations that the Iranian regime attempts to disseminate to the international community, this study examines coverage of the Arab Spring in the two main English-language Iranian news outlets, namely The Tehran Times and Press TV. The Tehran Times is a daily newspaper published in both print and online formats. It was established by Ayatollah Seyyed Mohammad Beheshti following the Iranian Revolution in 1979. According to Behesti, "[t]he Tehran Times is not the newspaper of the government; it must be a loud voice of the Islamic Revolution and the loudspeaker of the oppressed people of the world." Although the newspaper is not state-owned, it aims to disseminate the ideology of the Islamic Revolution and it is under considerable influence from the Iranian government. According to its website, The Tehran Times "makes a special effort to publish reports on cultural and religious issues," in addition to various other social issues. However, it has been demonstrated in several publications that The Tehran Times uncritically accepts and endorses the state ideology and the policies implemented by the Islamic Republic of Iran (Jaspal, 2013a, 2013b, 2014) Although there are no independent data concerning the circulation of the outlet, The Tehran Times claims to be "attracting readers from over 80 different countries" and that its website has "over 10,000 visitors each day."

Press $T V$ is a state-owned media outlet, which forms part of the Islamic Republic of Iran Broadcasting Corporation. It was launched in 2007 to "counter" Western news reporting on global issues (in particular, the Middle East), by providing the Iranian government's stance on matters of interest. The newspaper outlet frequently claims that Western media outlets are under the influence of "Zionists" and, thus, unreliable sources of news information. Conversely, it describes itself in more positive terms as the voice of reason (Jaspal, 2013a, 2013b). The outlet targets the 
West as its primary readership and is therefore useful in understanding the representations that Iranian seeks to disseminate to the West. According to its website ${ }^{2}$, the official vision statement of Press $T V$ includes

Heeding the often neglected voices and perspectives of a great portion of the world; Embracing and building bridges of cultural understanding;

Encouraging human beings of different nationalities, races and creeds to identify with one another;

Bringing to light untold and overlooked stories of individuals who have experienced the vitality and versatility of political and cultural divides firsthand.

Like The Tehran Times, Press TV is conservative in its ideological stance and has been described as a "mouth-piece" for the Islamic Republic of Iran. Given its official affiliation to the Iranian government, it does indeed disseminate social representations that are consistent with the Iranian regime. It is noteworthy that press censorship in Iran has resulted in the rapid and permanent closure of various newspaper outlets

The newspapers' websites feature online databases of published articles. Using the keywords 'Arab Spring', 'Islamic Awakening', 'Syria', 'Egypt', 'Tunisia', 'Libya', 'Saudi Arabia' and 'Bahrain', the author conducted a search of the online databases for articles published between 1 April 2012 and 1 April 2013. This period was selected in order to explore media coverage in the aftermath of the Arab Spring revolutions and the ongoing conflict in Syria, in order to avoid polarization around particular events. The selected period was deemed to be relatively less eventful than the previous 12 months in which both the Egyptian and Libyan leaders were overthrown. This was ideal because the research aim was to examine general media coverage on the Arab Spring as a whole. 324 articles published during this one-year period contained one or more of these keywords and were included in the output. All of these articles were pre-screened for their relevance to the Arab Spring and 14 irrelevant articles were discarded. The remaining 310 articles were subsequently analyzed. The aim of the study was to provide preliminary insight into the dominant themes that characterized English-language Iranian media coverage of the Arab Spring, rather than to provide a longitudinal overview of its coverage in Iran. Therefore, it was decided that a relatively small and well-circumscribed corpus of articles published during a short space of time would be adequate for fulfilling this research aim.

\section{Analytical procedure}

The corpus was analyzed using a social constructionist variant of qualitative thematic analysis, which has been described as "a method for identifying, analyzing and reporting patterns (themes) within data" (Braun \& Clarke, 2006, p. 78). The constructionist variant of thematic analysis is a language-oriented analytical technique for identifying patterns of meaning within a data set with particular foci on the micro and macro levels of linguistic analysis. It can be used to integrate discourse, cognition and power, bridging the epistemological positions of social constructionism and realism. The patterns of meaning identified in the analysis are represented as "themes". The technique can provide insight into how social reality is constructed in talk and text, acknowledging the possibilities offered by, and potential constraints imposed by, social power relations. Thematic analysis can help to reveal the rhetorical strategies for affirming and contesting hegemonic and polemic social representations and was therefore deemed suitable for use in this study of social 
representations of the Arab Spring. The method provides insight into how "reality," as we understand it, is constructed (rather than reflected) in talk and text. Thus, we are not looking for an "objective" reality but rather the discursive resources (e.g., metaphor, argument) that are employed in order to construct it (Burr, 2003). Thematic analysis was considered more useful than content analysis, for instance, due to its specific theoretical foci, which lie in describing (i) control, that is, how groups exert control over others through persuasion or by constructing their agenda as 'natural'; (ii) the 'discourse access profile', that is, the audiences and media to which stakeholders can disseminate their social representations; (iii) social cognition, namely that discourse can create and feed into social representations; and (iv) rhetorical strategies, namely the ways in which stakeholders describe, rationalize, justify, defend and contest particular versions of climate change. This can provide an analysis which goes beyond mere description, creating scope for the development of theory in the aforementioned areas.

Here the method is employed in order to identify dominant themes in the English-language Iranian media coverage of the Arab Spring. Both the author and a research assistant conducted preliminary analyses of the corpus and met to discuss its content and the emerging themes which appeared to capture the essential qualities of the articles. First, each article was individually coded in accordance with the research questions. These initial codes included inter alia the general tone of the article, categorization (e.g. "regime"), positioning (e.g. victimhood versus perpetrator), particular forms of language (e.g. metaphor), and emerging patterns within the data. Second, these initial codes were collated into potential themes, which captured the essential qualities of the articles analyzed. The full list of themes included: (i) Anchoring the Arab Spring to Islamic struggle; (ii) Glorifying the role of the Islamic Republic in the Islamic Awakening; (iii) Negativizing foreign interference; (iv) Dichotomization of "good" and "evil"; and (v) Normalizing al-Assad. Third, the preliminary themes were arranged into a coherent narrative structure, which best reflected the analysis. This process resulted in the identification of two superordinate themes, namely: (i) "Islamic Awakening": Islamicizing the Arab Spring, and (ii) "Bashar al-Assad is not Muammar al-Gaddafi": Compartmentalizing the Syrian Ally. The two superordinate themes, and the original sub-themes upon which they were based, were reviewed rigorously against the corpus in order to ascertain their compatibility. Specific extracts from the articles, which were considered vivid, compelling and representative of the themes, were selected for presentation in this article. The sources of the extracts are presented as endnotes.

\section{ANALYSIS}

This section outlines the following two themes: (1) "Islamic Awakening": Islamicizing the Arab Spring, and (2) "Bashar Al-Assad is not Muammar Al-Gaddafi": Compartmentalizing the Syrian Ally.

\section{"Islamic Awakening": Islamicizing the Arab Spring}

Most articles in the corpus Islamicize the Arab Spring, most frequently by referring to it as an "Islamic Awakening" or by describing it as "the spread of Islamic Awakening ideology in the Arab world."3 Most articles rely on Iranian political sources (such as the Iranian Supreme Leader Ali Khamenei and Iranian government ministers) in order to legitimize claims regarding the role 
of Islamic Awakening ideology in facilitating the Arab Spring. Ali Khamenei, for instance, is quoted as emphasizing the "Islamic nature" of the Arab Spring:

1. The pro-democracy uprising in certain Arab countries are Islamic in nature [...] The people's Islamic slogans in regional revolutions and the role of those who believe in Islam in organizing massive demonstrations and toppling corrupt regimes all prove that the movement is Islamic. ${ }^{4}$

2.1000s of Tunisians march in support of Islamic party [...] Ennahda, a well-organized movement, was repressed under Ben Ali's secular rule and capitalized on the revolutionary fervor to win subsequent elections ${ }^{5}$

In extract 1, it is acknowledged that the Arab Spring typically refers to the pro-democracy uprising in Arab countries, but the "pro-democracy uprising" is described specifically as "Islamic in nature." This also serves to anchor Islamic ideology to democracy, constructing Islamic Awakening ideology as being naturally conducive to democracy. The lack of democracy during the Shah's rule in Iran has consistently been presented by the Iranian government as a catalyst for the 1979 Iranian Revolution (Amuzegar, 1991). Yet, the democratic status of the Islamic Republic of Iran is questionable (Farhi, 2011), which suggests that the anchoring of Islamic revolutionary ideology to democracy may constitute a rhetorical technique for legitimizing actions that favor internal interests. Moreover, it can bolster ingroup identity cohesion (Moliner, 1993). Such a rhetorical strategy is similarly observable in the corpus, where the Islamic character of the Arab Spring movements is emphasized through reference to the "Islamic slogans" and the "Islamic beliefs" of the organizers of the demonstrations. This is presented as "evidence" for the Islamic nature of the Arab Spring.

In the corpus, there is a sense that secular government is inherently destructive to democracy, given the alleged supremacy of Islamic ideology in safeguarding democracy. As exemplified by extract 1, articles represent Islam's opposition to "corrupt [secular] regimes" as testimony to the Islamic character of the movements. Moreover, in extract 2, Ennahda is said to be supported by "1000s of Tunisians," which emphasizes popular endorsement of the party and its Islamist objectives. Yet, it is also noted that the Islamic party was "repressed under Ben Ali's secular rule," thereby constructing an inherent repression of "Islamic democracy" under "secular dictatorship." The people themselves are said to be acquiring awareness of the allegedly antidemocratic nature of secularism:

3. Islamic Awakening [is the] main driving force behind regional revolutions [...] people are rediscovering their faith. It is an Islamic Awakening without a doubt [...] this should be called an Islamic Awakening because you see now what the people are asking for and the result of the elections also shows what people are asking is going back to their own roots, their own religion and they no longer want those secular governments. ${ }^{6}$

As is consistent across the corpus, extract 3 represents the "Islamic Awakening" as key motivational factor underlying the Arab Spring revolutions. Like many other articles, this one anchors the Arab Spring to the rediscovery of Muslim faith, which is said to evidence its Islamic 
character. Crucially, secularism is represented as being inadequate for safeguarding democracy and only the crystallization of Islamic rule in Arab countries is represented as being conducive to a democratic system. As highlighted in extract 3, what democratic elections allegedly reveal is a return to "their own roots" and "their own religion," referring to a rejection of both Western culture and a revitalization of Islam. "Roots" and "religion" objectify the revolutionary protests, creating a representation of ethnic and religious survival. Consistent with the negativization of secularism in the Iranian press, extract 3 represents the Arab people as rejecting "secular governments" due to their allegedly un-democratic character.

Secularism is represented as a Western phenomenon. Accordingly, many articles in the corpus represent the West and particularly the US as being undemocratic, dictatorial and Islamophobic. As exemplified by extract 3, articles implicitly construct both indigenous Arab culture and Islam as being subject to some form of external (Western) threat, which the Islamic Awakening is allegedly mitigating. This form of propaganda simplifies the complexity of the Arab Spring by identifying a clear "threat" to the ingroup. In short, the Arab Spring is represented as a "re-indigenization" of Arab/ Muslim countries:

4. The Islamic revival, which has been such a striking feature of the Arab Spring, should be seen as a rejection of Western meddling and of Western control and a reaffirmation of Muslim identity. ${ }^{7}$

As in extract 4, articles construct the central goal of the Arab Spring as being the rejection of the West and its alleged acts of "meddling" and "control" in Arab countries, and there is a call for greater efficacy for the Muslim ingroup (Jaspal, 2013a).

Many articles in the corpus do acknowledge the Arabs' opposition to their national (secular) governments, although in most cases these national governments are constructed as "puppet rulers" of the United States. This implies that there is widespread popular resistance to the US:

5. As a result of the Islamic Awakening, the Saudi people are fed-up with the violation of their rights by their "puppet rulers" [...] such "dictatorial moves" [suppressing protests] will not hinder the waves of the Islamic Awakening in the region, but will, on the contrary, put forward the downfall of the Al Saud regime. ${ }^{8}$

6. The Persian Gulf regimes of Saudi Arabia and Qatar fund and support terrorist groups in the Arab countries to ramp up radicalization in the region in order to fight the growing influence of the Islamic Republic of Iran among their nations ${ }^{9}$

7. However, the dispatch of the [US] troops is clearly in line with the United States' general policy of maintaining the security of Jordan and protecting it from the waves of the Islamic Awakening, which, sooner or later, are expected to reach the country [...] Jordan is a red line for the United States and its regional proxy Israel. Over the years, Jordan has acted as a buffer state for the Zionist regime and any political change in the country could ruin the U.S. efforts to guarantee the security of Israel. ${ }^{10}$ 
In extracts 5 and 6, there is a condemnation of the Saudi Arabian government, which is represented as a "puppet" government of the US. This objectification of the "malevolent" Saudi outgroup serves to represent it as an offshoot of the larger US enemy, commonly referred to as the "Big Satan" in Iranian political discourse. By strategically quoting various key figures in the Iranian government, articles represent the decline of various Arabian governments as being imminent. This decline is implicitly attributable to their "puppet" status and reliance upon the US, which participants in the Islamic Awakening allegedly reject. Furthermore, Saudi decline is attributed to the Saudi ruler's adherence to "dictatorial moves" which allegedly curtail the rights of the populace to express their desire for "re-indigenization." Although it is observed that there is a "growing influence of the Islamic Republic of Iran among their nations," this is not inconsistent with "re-indigenization" due to the constructed centrality of Islam in the Arab Spring and the proclaimed centrality of Islam to the Islamic Republic's ideology and influence.

In extract 5, the supposedly non-democratic and malevolent character of some Arab governments is further demonstrated through reference to the notion that they "fund and support terrorist groups." Given that these countries are frequently represented as proxies or "puppets" of the U.S., the U.S. too is implicated in such wrongdoing. This is particularly observable in extract 7, which highlights the U.S. policy of "protecting [Jordan] from the waves of the Islamic Awakening." This represents the US as artificially "protecting" a regime that allegedly lacks legitimacy due to supposed popular opposition to it. The democratic aspirations of the Arab people are constructed as being subordinate and secondary to U.S. interests, namely "its regional proxy Israel." This is rhetorically powerful given widespread opposition to Zionism, which is generally regarded in the Muslim Middle East as being destructive to Arab, and particularly Palestinian, rights (Webman, 2010). In short, the U.S. and its regional allies are represented as going to whatever lengths necessary (including the sponsorship of terrorism) in order to protect themselves and their interests from the "waves of the Islamic Awakening."

In face of the disunity allegedly brought about by U.S. policy, articles construct the "Islamic Awakening" as an opportunity for re-establishing Islamic unity around collective opposition to external forces, such as the U.S. and Zionism:

8. The Algerian official [...] said Muslim countries should maintain unity against common threats $^{11}$

9. The secretary of Iran's Supreme National Security Council has said that the enemies are making every effort to promote Islamophobia because the world's nations are embracing Islam. $^{12}$

10. Khamenei has advised the leaders of countries that have experienced the Islamic Awakening to keep a safe distance from the hegemonistic powers. ${ }^{13}$

These articles converge in representing external forces as hindering the Islamic Awakening and strategically quote key figures in the Arab and Muslim world in order to construct Muslim unity as paramount. This propaganda protects identity cohesion in face of discontinuity (Moliner, 1993). In extract 8, the Algerian foreign minister is strategically quoted as calling for Muslim unity in the context of threats to "Muslim countries" which suggests that Islam is jeopardized by external forces. 
Many articles in the corpus represent the West as opposed to the "Islamic Awakening," which in turn is represented as posing a threat to the continuity of Islam in the region. In reference to the controversial anti-Islam film Innocence of Muslims which was posted on YouTube in July 2012, extract 9 strategically quotes the secretary of Iran's Supreme National Security Council as accusing "the enemies" (namely the U.S. and Israel) of creating and disseminating anti-Islamic material in order to engineer Islamophobic sentiment in the world. Crucially, this is said to constitute a response to the notion that "the world's nations are embracing Islam," an apparent reference to the Islamic Awakening. Articles construct a context of intergroup suspicion which rationalizes statements like the one made by Ayatollah Khamenei, as reported in extract 10. It is argued that the "hegemonistic powers," primarily the U.S. and Israel, have malevolent intentions (indicated by the advice that one maintain a "safe distance" from them). It has been observed that the propaganda mode of communication is inherently divisive from an intergroup relations perspective and that it seeks to impose discontinuity and incompatibility between social groups (Moscovici, 1961).

The Iranian press constructs linkage between the Islamic Awakening and its anti-Zionist policy, which is habitually represented as a "Muslim duty" (Jaspal, in press):

11. Commenting on the wave of the Islamic Awakening rolling across the Muslim world, [the secretary of Iran's Supreme National Security Council] said that the issue of Palestine and the campaign against the Zionist regime is a common issue among Muslim nations. There is a necessity that Muslim countries use the opportunity provided by the Islamic Awakening and promoting unity. ${ }^{14}$

12. The spread of the Islamic Awakening ideology in the Arab world and its impact on resistance movements in the region should be described as a new breath for the anti-Zionist campaign $^{15}$

13. Opening the session, Karimian made a brief speech in which he pointed to the Islamic Awakening and the Islamic resistance of nations as major tools in leading the Zionist regime toward the end of its life. ${ }^{16}$

In extract 11, the secretary of Iran's Supreme National Security Council invokes the Iranian regime's archenemy Israel, which it refers to as the "Zionist regime," as a "common issue among Muslim nations." Thus, it is assumed that Muslims share, or ought to share, a commitment to antiZionism (Jaspal, in press). The article reporting this statement creates linkage between the Islamic Awakening and the necessity of anti-Zionism in the Muslim world, partly by positioning this statement within commentary "on the wave of the Islamic Awakening" but also by invoking the notion that the Islamic Awakening provides an opportunity for "unity" among Muslims. One implicit means of safeguarding unity is a shared commitment to anti-Zionism, which in turn bolsters identity cohesion. Thus, the Arab Spring is strategically Islamicized and deployed as a means of mobilizing Muslims against presumed common enemies, here Israel (Jaspal, 2013b, in press). In some articles, the already positive outcomes of the Islamic Awakening are invoked. For instance, it is observed that the Islamic Awakening ideology has benefitted "resistance movements 
in the region" (e.g. Hamas and Hezbollah). The metaphor of "new breath" accentuates both the vitality of anti-Zionist feeling in the Middle East but also the importance of the Islamic Awakening for safeguarding anti-Zionism. As a compelling popular concern in the Muslim Middle East, it clearly has much mobilizing potential. Moreover, as highlighted in extract 13, the Islamic Awakening is constructed as being essential for, and successful in, realizing the allegedly important aim of destroying Zionism.

Articles construct the role of the Islamic Republic of Iran as being pivotal in the creation and sustenance of the Islamic Awakening. This is achieved partly by strategically quoting leading political figures in the Islamic Republic, which suggests that they are best positioned to comment on political developments in the region, but also by anchoring the Arab Spring to elements of the Islamic Republic's politico-historical development. For instance, as observed above, the Islamic Awakening is consistently represented as a popular rejection of U.S. imperialism, which is consistent with Iran's hegemonic narrative concerning its own Islamic Revolution in 1979. The following extracts exemplify the notion of American (and Zionist) imperialism and the important role of the Islamic Republic in mitigating it:

14. Iranian Majlis Speaker Ali Larijani said on Sunday that the era of a "false" American empire has come to an end, highlighting the key role Iran can play at this critical juncture [...] the Islamic Republic acted wisely during that period and foiled its plots [...] and Iran's strategy brought about the (Islamic) Awakening in the region." ${ }^{\prime 17}$

15. The Iranian revolution serves as the roadmap for the Islamic Awakening. ${ }^{18}$

According to extract 14, given that the Islamic Awakening marks the end of the "false" American empire, the Islamic Republic can play a particularly important role "at this critical juncture." This may be attributed to the sense of self-efficacy and national success that is woven into the Islamic Republic's political-historical narrative in "defeating" US imperialism, symbolized by the former Shah of Iran, in dominant Iranian cultural consciousness (Amuzegar, 1991). In extract 15, the notion of an "Islamic Awakening" is supported through reference to the Iranian revolution, and it is implied that the Islamic Awakening constitutes a continuation of the 1979 Islamic revolution in Iran. The metaphor of a "roadmap" suggests that the 1979 Islamic Revolution constitutes a perfect example of revolutionary success and that it should be imitated in the Arab Spring revolutions. Unsurprisingly, articles in the corpus draw attention to the fact that "Tehran [is] to host Islamic Awakening conference in April," 19 which further reiterates the centrality of Iran in the continuation of the Islamic Awakening. In short, articles attribute the start of the Islamic Awakening primarily to "Iran's strategy." For instance, in extract 14, Larijani is quoted as arguing that it is Iran's efforts to "foil" U.S. "plots" which have sensitized the Arab people to both the "threat" of the US, to the shortcomings of their own leaders and to the benefits of Islamic Awakening. However, not all Arab leaders are negativized and not all protests are examples of Islamic Awakening, as discussed next.

\section{"Bashar Al-Assad is not Muammar Al-Gaddafi""20: Compartmentalizing the Syrian Ally}


While the Iranian press clearly endorses the "Islamic Awakening," the Syrian conflict is not represented as being a part of it. There is a consistent legitimization of the Syrian government led by al-Assad and a parallel delegitimization of the Syrian anti-government rebels through their characterization as (foreign) terrorists. In short, there is a dichotomization of benevolence (the Syrian regime) and malevolence (opponents of the Syrian regime).

Bashar al-Assad is in fact constructed as a benevolent leader and his actions and policies as facilitating the "Islamic Awakening." For instance, the Iranian press emphasizes his commitment to anti-Zionism, which is said to lie at the heart of the Islamic Awakening and Islamic identity, more generally (Jaspal, 2014). Conversely, actors such as the Bahraini authorities are systematically demonized - they and their allies are represented as hindering the Islamic Awakening:

16. Saudi and other Persian Gulf troops were deployed in Bahrain to help the Western-backed Sunni monarchy quell a wave of anti-government protests demanding a greater role for the country's Shia majority [...] “This government doesn't hear our voices and I can't forgive what the troops did in my country," she [a protestor] said. ${ }^{21}$

While the anti-government protestors in Bahrain are depicted as demanding legitimate rights for the Shia majority, the Bahraini authorities and the Western nations that "back" them are conversely represented as hindering the democratic process. There is a constructed silencing of the Shia majority through the use of military force, which is suggested in the quote from the protestor in extract 16. The actions of "Saudi and other Persian Gulf troops" are represented as being "unforgiveable" and the notion of Western support for dictatorship is reiterated.

Consistent with the notion that "regional dictators" rely upon the US in order to survive, several articles depict the Bahraini authorities as being cowardly in face of their people's alleged commitment to the Islamic Awakening:

17. The Bahraini regime last week issued a new law that shows just how wobbly-scared it is of its own people [...] But this Guy Fawkes disguise has the Al Khalifa regime quaking in their boots $[\ldots]$ retarded and reactionary regime [...] imposter Khalifas [...] parasite regime [...] like a parasite and a host, the Khalifa thugs have sucked the lifeblood of the Bahraini people ${ }^{22}$

The extract refers to Bahrain's banning of the "V for Vendetta" masks (Pollak, 2013). The notion that the Bahraini regime should be "wobbly-scared" of its people is intended to demonstrate its ineligibility to govern Bahrain. Moreover, the article actively represents the Bahraini authorities as being foreign and dangerous to the Bahraini people - this is exemplified by the compound "imposter Khalifas" and "parasite regime." Both of these constructions represent the authorities as maliciously taking advantage of the indigenous population of Bahrain for personal gain. The metaphor of "imposter" accentuates the notion of fraudulence and personal gain, while the metaphor of "parasite" positions the Bahraini people as the host from whom "the Khalifa thugs have sucked the lifeblood." Thus, there is a sense that the Khalifa rulers in Bahrain are inherently selfish, exploitative and are concerned primarily with their own survival, rather than that of the 
Bahraini people. This metaphorical construction serves to represent the Al Khalifa primarily as a dangerous threat to the Bahraini people.

Threat dynamics function only when some form of intergroup difference can be constructed and accentuated. In addition to representing the Khalifa as a parasite and the Bahraini people as the host, the extract constructs the Khalifa family as a foreign outgroup. Thus, there is an accentuation of intergroup difference in Iranian propaganda. Some articles, as exemplified by extract 16, accentuate their Sunni background and the Shia majority of Bahrain. Furthermore, negative adjectives are consistently employed in order to describe the regime. For instance, the adjectives "retarded and reactionary" metaphorically construct the authorities as being undemocratic and closed to any political or social reform, which is intended to "explain" the popular uprising against the regime. Moreover, the term "thugs" unequivocally deprives the Khalifa family of any legitimacy and right to rule, since it constructs them as a criminal group, which is consistent with their characterization as "retarded and reactionary."

There is a similar negativization of other regional rulers who were opposed in the Arab Spring uprisings:

18. Two years after an Arab Spring revolution overthrew authoritarian ruler Hosni Mobarak ${ }^{23}$

19. Tunisians overthrew their long-ruling dictator Zine El Abidine Ben Ali ${ }^{24}$

20. The autocracy in Kuwait is stopping true democratic life. ${ }^{25}$

21. Washington earned ill will in the region in the past by backing dictators and taking "a very clear" biased approach against the Palestinians and for Israel [...] Mobarak's compliance with Washington's agenda in the Middle East ${ }^{26}$

In extracts 18 and 19, the former leaders of Egypt and Tunisia are anchored to authoritarianism and dictatorship, respectively, and the people of these countries are constructed as having actively overthrown the leaders. This active role of the people in the "revolutions" is reinforced through use of the active voice. Similarly, in extract 20, the government of Kuwait is referred to as an "autocracy" which reinforces images of authoritarianism and dictatorship. Extract 21 represents the "dictatorship" of Mobarak as being consistent with "Washington's agenda" in the Middle East, and attributes anti-Americanism in the Middle East to alleged US support for "dictators," which is a consistent theme across the corpus. Thus, there is a generalization of US support for "dictators," its pro-Israel stance and the allegedly authoritarian actions of regional leaders. There is a clear sense that the Arab Spring/ Islamic Awakening was initiated by the people of the region in order to establish democracy in authoritarian and dictatorial countries, and the observation that the people succeeded in "overthrowing" these leaders crystallizes this notion.

Crucially, while the Iranian press constructs and emphasizes images of authoritarianism and dictatorship within the context of Egypt, Tunisia and Kuwait, there is no such representation of the Syrian government, which is conversely constructed as being representative of the people of Syria. This implies that democracy is a prevalent norm in the Middle East, that Syria is exemplary in its political system, and that Bahrain, Kuwait, Egypt and Saudi Arabia are somehow exceptional in being "autocratic."

This positive representation of the Syrian government allows the Iranian press to manifest overt support for the Syrian leader and to exclude Syria rhetorically from the Islamic Awakening: 
22. Bashar al-Assad is our [Iran's] red line, we will support him to the bitter end ${ }^{27}$

23. The [Iranian] ambassador emphasized that Iran will continue its support for the Syrian people and hailed the political initiative of the Syrian government and parliament to help resolve the nearly two-year conflict in the Arab country ${ }^{28}$

24. Support for Bashar Assad is part of our regional policy: confronting the hegemony of Israel in the area. The U.S. and Europeans want to enforce a change in Syria because they want to put a dictator over there in the name of democracy, which is the stooge of Israel ${ }^{29}$

In extract 22, the metaphor of "red line" constructs al-Assad as being pivotal to the wellbeing and continuity of Iran. Like an engine whose red line symbolizes the point after which its internal components are jeopardized, al-Assad's Syria is represented as constituting a defensive shield for the Islamic Republic of Iran and its ideology, without which Iran's interests would be harmed. It is argued in several articles in the corpus that Syria, as a leading player in the anti-Zionist campaign, constitutes a priority in Iran's foreign policy. It is implied that opposition to Syria would result in a pro-Israeli leader ("stooge of Israel") which would cause more harm in the region. This is a possible reference to the Palestinians, for whom there is much sympathy in the Muslim Middle East (Sawani, 2012). Consequently, the Iranian press explicitly manifests Iran's support for alAssad "to the bitter end." Yet, in order to deflect the criticism that Iran's foreign policy is inconsistent with the aspirations of the Syrian people, the Iranian press strategically quotes Iranian ministers as reiterating their support for the "Syrian people," in particular, rather than the Syrian regime. Thus, there is a superficial integration of the Syrian government and the Syrian people this is achieved partly by lauding the "political initiative" of the Syrian government which is implied to be beneficial for the Syrian people. Indeed, articles in the corpus emphasize the alleged solidarity between the Syrian people and the Syrian army/ Syrian government:

25. Every day we see people from each and every part of Syria crying for the Syrian Arab Army [SAA] to come and rescue them from the armed terrorists [...] Above all, the SAA is not an alien army that landed on Syrian land by UFOs; every single soldier in the SAA is a member of the Syrian family ${ }^{30}$

Here, the Syrian people are depicted as siding with the Syrian government and, more specifically, as "crying for the Syrian Arab Army to come and rescue them." The Syrian people are said to regard the anti-government fighters as "armed terrorists," rather than as freedom fighters, which is further reiterated through the notion that the Syrian people indeed need to be "rescued" from them. This in turn contests the notion that the Syrian army has committed atrocities against the Syrian people, which has been reported in international media outlets (Friedman, 2012). Thus, there is a constructed divergence between the intentions of the anti-government ("foreign-backed") fighters and the aspirations of the Syrian people. Moreover, in contrast to the anti-government fighters who are consistently represented as being foreign, the Syrian Arab Army is constructed as being "indigenous" and, thus, naturally committed to the wellbeing of the Syrian people. Extract 25 ironically observes that the Syrian army is not "an alien army that landed on Syrian land by 
UFOs" in order to emphasize its indigeneity. This is further reiterated by referring to "the Syrian family" of which both the Syrian Arab Army and Syrian civilians constitute indivisible parts.

The Iranian press provides greater "voice" to President al-Assad than other outlets do, in order to exclude Syria from the remit of the Islamic Awakening. For instance, al-Assad is quoted as defending his position as president:

26. Syrian President Bashar Al-Assad has said that the government did not start the conflict and the militant groups were the ones killing Syrian citizens and destroying the country's infrastructure $^{31}$

Here the conflict is attributed to "militant groups," who are accused of initiating the conflict, and the notion that the Syrian people have demanded political change in the anti-government demonstrations is not acknowledged. Crucially, these militant groups are said to be engaged in civilian killings and in destroying national infrastructure, which distances these actions from the Syrian government/army who have been widely accused of them. Moreover, this serves implicitly to justify and "normalize" the Syrian government's response to "militant groups." This ties in with the overarching representation that the anti-government activity in Syria is not part of the Arab Spring/ Islamic Awakening, and that it is unrepresentative of the people's desires and interests because it endangers the Syrian people, in particular.

This in turn allows for the Iranian press's condemnation of the international community's censorious response to the Syrian government:

27. We condemn the Arab League's recent move to hand Syria's seat to a small group, which does not represent the Syrian people [...] It is a wrong decision to support the Syrian opposition with weapons by any means, and will cause big problems. It will cause problems for the Syrian people. ${ }^{32}$

In extract 27, Amir-Abdollahian, the Minister for Arab and African Affairs, is strategically quoted as condemning the Arab League's decision to recognize the National Coalition for Syrian Revolutionary and Opposition Forces (NCSROF) as the sole legitimate representative of the Syrian people. This act is constructed as being abnormal and illegitimate given the characterization of the NCSROF as a "small group which does not represent the Syrian people." In short, the Syrian people are represented as supporting al-Assad's government and not the "small group" that the Arab League has chosen to recognize. This ties in with the notion that the Arab League (and indeed the US and its allies) seek to overthrow the Syrian government for selfish gain, rather than any consideration for democracy or the Syrian people. By supporting and arming the group, the NCSROF is said to induce "big problems" for the Syrian people due to the constructed discrepancy between the anti-government forces and the Syrian people. The implicit aim here is to normalize al-Assad's government by constructing it as being the sole legitimate government of Syria which has the full support of the majority of the Syrian population and, thus, outside of the Arab Spring/Islamic Awakening. 


\section{DISCUSSION}

This article provides some preliminary insight into the dominant social representations observable in coverage of the Arab Spring in the two main English-language Iranian newspaper outlets, The Tehran Times and Press TV, which the Iranian regime seeks to disseminate. Firstly, the Iranian press constructs the Arab Spring primarily in terms of an "Islamic Awakening," which serves to accentuate Islamic solidarity and to construct a united front against secularism and the West. There is a social representation that the Arab Spring constitutes an "Islamic Awakening". Secondly, there is a delineation of the "Islamic Awakening" countries (such as Egypt, Libya and Tunisia) and Syria (the "victim of foreign-sponsored terrorism"). This constructs the social representation that Syria is benevolent and representative of the Syrian people and that the regimes in the Islamic Awakening countries are, conversely, malevolent and opposed to the will of their respective peoples. These two social representations encompass a range of dichotomies, namely (i) secularism versus theocracy, (ii) Western culture versus “indigenous" Islamic culture, (iii) democracy versus dictatorship, and (iv) benevolence versus malevolence, which have been outlined in this article. Through the propaganda mode of communication (Rouquette, 2003, 2004), the English-language Iranian press simplifies the Arab Spring by anchoring it to familiar Islamic imagery and by dichotomizing benevolence (the al-Assad regime) versus malevolence (the regimes in the Islamic Awakening countries). It accentuates the aggression of the regimes of the Islamic Awakening countries, while attenuating that of the Syrian people, instead attributing the aggression to "terrorists". It assimilates the revolutionary protests to religion and, more specifically, to the secularism versus theocracy divide, and represents the Arab Spring as a struggle for safeguarding Islamic values. Finally, the Islamic character of the Arab Spring is accentuated in order to represent it as relevant and universally important to the Islamic Ummah.

In Islamicizing the Arab Spring, the Iranian press represents Islamic unity as being paramount to its success, and downplays the social and political diversity that has characterized the Arab Spring protests. Although Islam constitutes a "core" identity for many in the Arab world (Sawani, 2012), it is simplistic to claim that Islamic revival alone lies at the heart of the Arab Spring. Yet, in the Iranian press, the Arab Spring is imbued with an intergroup dimension based primarily around "Islam versus West." This is strategically beneficial for the Islamic Republic of Iran, given its "ostracization" in the Middle East as a Shiite Muslim theocracy in a primarily Sunni-dominated region (Jaspal, 2013a). Following the 1979 Islamic Revolution in Iran, the country has found itself increasingly isolated from other countries, some of which continue to fear the spread of (Shiite) Iranian influence in their countries. By Islamicizing the Arab Spring, Iran is able to gloss over the sectarian divisions that underlie suspicion towards the Iranian government, and attempts to restore a sense of belonging, but also leadership, for Iran in the (predominantly Sunni Muslim) Middle East. This serves the function of creating identity cohension (cf. Moliner, 1993), despite the discontinuity and lack of cohesion characterizing Iranian-Arab relations.

The Islamicization of the Arab Spring also serves to validate and legitimize Iran's own 1979 revolution. Several articles in the corpus construct the Arab Spring as a "continuation" of the Iranian revolution by drawing a parallel between them. The Iranian revolution has been 
represented by the Islamic Republic as a means of "restoring" democracy in what was popularly regarded as a "monarchical dictatorship" led by Reza Shah (Amuzegar, 1991). Secularism and "Western values" were regarded as antithetical to "true democracy" and to the will of the Iranian people, since there was a widespread representation that the Western values that the Shah of Iran espoused were encroaching upon the national, cultural and religious norms of Iranians. Similarly, within the context of the Arab Spring, secularism (itself constructed as a "Western" phenomenon) is systematically represented as having "failed" in the countries in which the Arab Spring has been unfolding. There is a sense that, like the Iranian revolutionaries in 1979, the Arab protestors are collectively rejecting the secular political systems that have developed in their countries (allegedly as a result of interference from the US and Zionists). Interestingly, there is no invocation of the "Green Movement" protests that took place in opposition to the re-election of President Ahmadinejad in 2006, which were described as being the largest anti-government protests in Iran since the 1979 revolution (Al Jazeera, 2009). Thus, there is a strategic construction of the Arab Spring as a continuation of the 1979 Iranian revolution and a strategic omission of the 2006 Iranian protests, which glorifies Islamic theocracy, downplays political dissent in Iran and, thus, serves Iran's geopolitical interests. This serves the function of bolstering Iran's national self-esteem and constructs its own revolution as a trigger for the "positive" changes unfolding in the Arab world.

Given the coercive representation that the Arab Spring protests marked a popular desire for democracy, the Iranian press maintains the centrality of Islam in this by constructing Islamic government as being "naturally" conducive to democracy. Accordingly, in view of Iran's position as the first Islamic Republic in the region, as well as its alleged agency in "foiling" US/ Zionist conspiracies against Muslims, the Iranian press represents Iran as being uniquely positioned to lead the Islamic Awakening in the region and to expand its political and ideological influence. Similarly, Iran's Islamicization of the Arab Spring serves to accentuate Iranian influence in the region by disseminating and promoting key aspects of its ideology. At the most basic level, the Iranian press constructs Islamic theocracy as being the desired endresult of the Islamic Awakening and as an inherently superior political system (to secularism). Furthermore, the Iranian press consistently depicts anti-Zionism and anti-Americanism as core aspects of the "Islamic Awakening," which constructs two important tenets of Iranian state ideology as being widely shared by the Arab people (Clawson, 2004; Jaspal, 2013a). The Islamic Awakening is said to symbolize popular Arab dissatisfaction with Zionism and the State of Israel, in particular, which is discussed in relation to Egypt's formal alliance with the State of Israel. The Iranian Press employs the Arab Spring to "expose" the threats allegedly posed by Israel, the US and other countries in the Middle East, which serves to glorify the Islamic Republic's capability for identifying threats to the Islamic Awakening and to expand its own influence. The accentuation of intergroup difference (in the us versus them dichotomy) is evident in the corpus. It is implicitly argued that a "good" citizen will embrace Islamic theocracy as the "truly" democratic political system, reflective of the will of the Muslim people.

Yet, the Iranian press reproduces the Islamic Republic's selective support for the Arab Spring. While the Iranian press acknowledges and emphasizes popular opposition to the Islamic Awakening countries, it categorically rejects the notion that there is any popular opposition to the Syrian government (the "victim of foreign-sponsored terrorism"). The Iranian 
press appends negative value to the governments of the Islamic Awakening countries, referring to them as "puppets" of the US/ Israel, as authoritarian, dictatorial, cowardly, fraudulent and, in some cases, foreign entities. The US and Israel are portrayed as selfishly supporting violence and even terrorism against the Arab people in order to safeguard their own political interests. There is a clear warning that Islamic Awakening countries steer clear of Western influence which is constructed as anti-Islamic and, thus, "naturally" anti-democratic. The dichotomy of Western outgroup culture versus Islamic ingroup culture is mobilized in order to serve ingroup geopolitical interests.

Conversely, the Iranian press systematically defends al-Assad and the Syrian government by (i) emphasizing its anti-Zionist policy, which has consistently been constructed as a fundamental Islamic "quality" (Jaspal, 2014; Litvak, 1998), (ii) by praising the "political initiative" of the Syrian government and (iii) by denying that the majority of Syrians are at all dissatisfied with al-Assad's government. In fact, the anti-government fighters in Syria are represented as being "armed terrorists" and "militant gangs," stripping them of any legitimacy and denying that they in any way represent the desires and aspirations of the Syrian people. The Iranian press depicts the anti-government movement in Syria as a "small group," rather than a representative one, which should be condemned, rather than supported, by the international community. This provides an opportunity for delegitimizing the regionally influential Arab League, of which the Islamic Republic of Iran is not a part, and for reiterating the Islamic Republic's own political and ideological agenda. It is noteworthy that neither the secular nor authoritarian bases of al-Assad's government is at all mentioned in any of the articles analyzed, which presents a positive image of the Syrian government and "excludes" it from the Arab Spring. In short, while the leaders of the Islamic Awakening countries, the US, Israel and other Western countries are systematically represented as being malevolent players in the Arab Spring, al-Assad is constructed as a benevolent player who must be protected in order for the Islamic Awakening to succeed.

\section{Conclusion}

This article outlines the systematic "instrumentalization" of the Arab Spring in the Iranian press - it is employed to validate and accentuate tenets of the Islamic Republic of Iran's revolutionary ideology and to support its political interests in the region. The Tehran Times and Press TV are not just news outlets which aim to transmit news and to educate the world about current affairs. Rather, they constitute instruments for disseminating a particular political and ideological agenda and for convincing their readership of its validity. Accordingly, these newspaper outlets do provide important insights into the representations that the Iranian regime wishes to disseminate and legitimize in the international community - the present analysis provides a qualitative snapshot of the representational practices of the Islamic Republic in relation to the Arab Spring. The propaganda means of communication ensures that important ingroup functions are served. More specifically, the newspapers accentuate the role that the Islamic Republic can play in "safeguarding" the Islamic Awakening and for ensuring that its Islamist "goals" are realized. The Iranian press employs the Arab Spring as a means of accentuating the threats allegedly posed by Iran's foes, primarily the US and Israel, and as a means of increasing Iran's (potential) influence in the region. 
It cannot be unequivocally known whether the representations outlined in this article are uncritically accepted by the Iranian general population in the absence of empirical research into public understanding. Thus, it would be beneficial to build on this research, firstly, by conducting survey-based research into the attitudes of the Iranian general population in order to gauge perceptions of the Arab Spring and, secondly, by examining experimentally whether mere exposure to such media representations leads to acceptance among the readership. Public understanding of the Arab Spring was not the focus of this article but it should not be ignored in future research. It is noteworthy that many Iranians live in a context surrounded by coercive and hegemonic government-endorsed representations embodied at every social and institutional level in the Islamic Republic of Iran. This makes resistance to such representations difficult. Moreover, it must be remembered that propaganda is explicitly intended to shape public perceptions (Rouquette, 2003, 2004). Thus, far from realizing their stated aims of being the "loudspeaker of the oppressed people of the world" and of "building bridges of cultural understanding," these newspaper outlets use propaganda in a transparent attempt to divide the region, to accentuate external threat imagery and to steer the Arab Spring in a direction that is favorable to the Islamic Republic of Iran and to the Islamic Republic alone.

\section{ACKNOWLEDGEMENTS}

The author would like to thank the Iran Media Program, Annenberg Public Policy Center for their financial support of this research project, and several anonymous reviewers for their constructive and insightful feedback on earlier versions of this article.

\section{REFERENCES}

Ahmed, T.S. (2005). Reading between the lines - Muslims and the media. In T. Abbas (ed.), Muslim Britain: Communities under Pressure (pp 109-26). London: Zed Books.

Ajami, F. (2012). The Arab Spring at one. Foreign Affairs, March/April, 2012.

Alhasan, H.T. (2011). The Role of Iran in the Failed Coup of 1981: The IFLB in Bahrain. The Middle East Journal, 65(4), 603-617

Aliboni, R. (2011). The international dimension of the Arab Spring. The International Spectator, 46(4), 5-9

Al Jazeera (2009). Poll results prompt Iran protests. Al Jazeera, 14 June 2009.

Amuzegar, J. (1991). The Dynamics of the Iranian Revolution: The Pahlavis' Triumph and

Tragedy. Albany: State University of New York Press.

Anderson, L. (2011). Demystifying the Arab Spring. Foreign Affairs, May/June 2011.

Ansari, H. (2005). Attitudes to jihad, martyrdom and terrorism among British Muslims. In T.

Abbas (ed.), Muslim Britain: Communities under Pressure (p.144-163). London: Zed Books.

Billig, M. (1988). Ideological dilemmas: A social psychology of everyday thinking. London:

Sage.

Braun, V. \& Clark, V. (2006). Using thematic analysis in psychology. Qualitative Research in Psychology, 3, 77-101.

Breakwell, G.M. (2001). Social representational constraints upon identity processes. In K.

Deaux \& G. Philogène (eds.), Representations of the social: bridging theoretical traditions (pp. 271-284). Oxford: Blackwell. 
Brown, T.B. (2012). The representation of the Syrian uprising in Western and Arab media (with reference to Newsweek, Al-Jazeera and the use of New Media). Unpublished manuscript. Available at:

https://www.academia.edu/2258678/The_Representation_of_the_Syrian_Uprising_in_Western _and_Arab_Media

Burr, V. (2003). Social constructionism. London: Routledge.

Carvalho, A. (2007). Ideological cultures and media discourses on scientific knowledge: rereading news on climate change. Public Understanding of Science, 16(2), 223-243.

Clawson, P. (2004). The paradox of anti-Americanism in Iran. Middle East Review of International Affairs, 8(1), 16-24.

Dallmayr, F. (2011). Radical Changes in the Muslim World: Turkey, Iran, Egypt.

Globalizations, 8(5), 639-646

Danesh, T. \& Hug, A. (2011). Introduction and policy recommendations. In T. Danesh \& A. Hug (eds.), Iran Human Rights Review: Access To Information (pp. 4-7). London: The Foreign Policy Centre.

Elcheroth, G., Doise, W., \& Reicher, S. (2011). On the knowledge of politics and the politics of knowledge: How a social representations approach helps us rethink the subject of political psychology. Political Psychology, 32, 10.1111/j.1467-9221.2011.00834.x

Farhi, F. (2011) Tehran's Delayed Spring? Globalizations, 8(5), 617-621

Friedman, U. (2012). The five worst atrocities of the Syrian uprising. Foreign Policy, May 2012.

Galal, E. \& Spielhaus, R. (2012). Covering the Arab Spring: Middle East in the Media - the Media in the Middle East. Global Media Journal, 2(1). Online publication.

Khondker, H.H. (2011) Role of the New Media in the Arab Spring, Globalizations, 8(5), 675679

Jaspal, R. (2011). The construction and management of national and ethnic identities among British South Asians: An identity process theory approach (Unpublished doctoral dissertation). Royal Holloway, University of London, Egham, UK.

Jaspal, R. (2013a). Anti-Semitism and Anti-Zionism in Iran. Israel Affairs, 19(2), 231-58.

Jaspal, R. (2013b). Israel in the Iranian Media: Demonizing the "Zionist Regime". Israel Journal of Foreign Affairs, 7(1), 77-86

Jaspal, R. (2014). Antisemitism and anti-Zionism: representation, cognition and everyday talk. Farnham: Ashgate.

Jaspal, R. (in press). Representing the "Zionist Regime": Mass Communication of AntiZionism in the English-language Iranian Press. British Journal of Middle Eastern Studies. Jaspal, R., Nerlich, B. \& Cinnirella, M. (2014). Human Responses to Climate Change: Social Representation, Identity and Socio-Psychological Action. Environmental Communication: A Journal of Nature and Culture.

Kamalipour, Y.R. (2010). Media, Power, and Politics in the Digital Age: The 2009

Presidential Election Uprising in Iran. Lanham: Rowman \& Littlefield.

Karsh, E. (2002). The Iran-Iraq War, 1980-1988. Botley: Osprey Publishing. 
Kurzman, C. (2012). The Arab Spring: Ideals of the Iranian Green Movement, Methods of the Iranian Revolution. International Journal of Middle East Studies, 44, 162-165.

Lesch, D.W. (2011). The Arab Spring - and Winter - in Syria. Global Change, Peace \& Security, 23(3), 421-26.

Litvak, M. (1998). The Islamization of the Israeli-Arab Conflict: The Case of Hamas. Middle Eastern Studies, 23(1), 148-163.

Litvak, M. (2006). The Islamic Republic of Iran and the Holocaust: Anti-Semitism and AntiZionism. Journal of Israeli History, 25(1), 267-84

Moliner, P. (1993). Cinq questions à propos des représentations sociales. Cahiers Internationaux de Psychologie Sociale, 20, 5-14.

Morady, F. (2011). Who rules Iran? The June 2009 election and political turmoil. Capital \& Class, 35(1), 39-61

Moscovici, S. (1961). La psychanalyse, son image et son public. Paris : PUF.

Moscovici S (1963) Attitudes and opinions. Annual Review of Psychology 14: 231-260.

Moscovici S (1973) Foreword. In C. Herzlich (ed.), Health and Illness: A Social Psychological Analysis. London: Academic Press, ix-xiv.

Moscovici, S. (1988). Notes towards a description of social representations. European Journal of Social Psychology, 18, 211-50.

Olausson, U. (2011). "We're the ones to blame": Citizens' representations of climate change and the role of the media. Environmental Communication: A Journal of Nature and Culture, 5(3), 281-299.

Perthes, V. (2012). Europe and the Arab Spring. The International Spectator, 46(4), 5-9. Pollak, S. (2013). Bahrain bans "V for Vendetta" Masks. Time World, 27 February 2013. Rouquette, M.-L. (2003). Eléments pour une théorie minimale des sectes. Psychologie et Société, 6, 9-22.

Rouquette, M.-L. (2004). Propagande et citoyenneté. Paris : PUF.

Salaita, S. (2012). Corporate American media coverage of Arab revolutions: the contradictory message of modernity. Interface: A Journal For and About Social Movements, 4(1), 131-45. Sawani, Y.M. (2012) The 'end of pan-Arabism' revisited: reflections on the Arab Spring. Contemporary Arab Affairs, 5(3), 382-397

Semati, M. (2008). Media, Culture and Society in Iran: Living with Globalization and the Islamic State. London: Routledge.

Smith, N., \& Joffe, H. (2013). How the public engages with global warming: A social representations approach. Public Understanding of Science, 22, 16-32.

Sweetser, K.D. \& Brown, C.W. (2010). An exploration of Iranian communication to multiple target audiences. Public Relations Review, 36, 238-248.

UN News Service (2013). UN chief, United States Secretary of State, urge political solution to Syrian crisis. UN News Center, 25 July 2013.

Wagner, W., Duveen, G., Farr, R., Jovchelovitch, S., Lorenzi-Cioldi, F, Markova, I. \& Rose, D. (1999). Theory and method of social representations. Asian Journal of Social Psychology, 2(1), 95-125

Webman, E. (2010). The challenge of assessing Arab/Islamic antisemitism. Middle Eastern Studies, 46(5), 677-98. 
Wojcieszak, M., Smith, B. \& Ennayat, M. (2012). Finding a way: How Iranians reach for news and information. The Iran Media Program: University of Pennsylvania.

Wolfsfeld, G., Segev, E. \& Sheafer,T. (in press). Social media and the Arab Spring: Politics comes first. The International Journal of Press/Politics.

${ }^{1} \mathrm{http}: / /$ tehrantimes.com/nnnnnnnnnabout-ttnnnnnnnnn

2 http://www.presstv.com/about.html

${ }^{3}$ Tehran Times, 3 December 2012

${ }^{4}$ Tehran Times, 11 December 2012

${ }^{5}$ Tehran Times, 17 February 2013

${ }^{6}$ Press TV, 11 July 2012

${ }^{7}$ Tehran Times, 21 September 2012

${ }^{8}$ Press TV, 28 March 2013

${ }^{9}$ Press TV, 2 April 2013

${ }^{10}$ Tehran Times, 20 October 2012

${ }^{11}$ Tehran Times, 15 March 2013

${ }^{12}$ Tehran Times, 7 September 2012

${ }^{13}$ Tehran Times, 11 December 2012

${ }^{14}$ Tehran Times, 7 September 2012

${ }^{15}$ Tehran Times, 3 December 2012

${ }^{16}$ Tehran Times, 24 September 2012

${ }^{17}$ Tehran Times, 28 October 2012

${ }^{18}$ Tehran Times, 11 December 2012

${ }^{19}$ Tehran Times, 27 February 2013

${ }^{20}$ Tehran Times, 3 November 2012

${ }^{21}$ Tehran Times, 15 March 2013

${ }^{22}$ Press TV, 3 March 2013

${ }^{23}$ Tehran Times, 27 December 2012

${ }^{24}$ Tehran Times, 11 February 2013

${ }^{25}$ Tehran Times, 27 October 2012

${ }^{26}$ Tehran Times, 23 September 2012

${ }^{27}$ Tehran Times, 19 January 2013

${ }^{28}$ Tehran Times, 5 March 2013

${ }^{29}$ Tehran Times, 16 March 2013

${ }^{30}$ Tehran Times, 3 November 2012

${ }^{31}$ Tehran Times, 4 March 2013

${ }^{32}$ Press TV, 31 March 2013 